\title{
Impact of Royal Jelly Supplement on Ewe's Milk Fat Content and Fatty Acid Profile During the Early Stage of Lactation
}

\author{
Akram Abdel Sattar El-Tarabany ${ }^{1}$, Omar Abdel Hamid Ahmed-Farid ${ }^{2}$, Sana Sayed Emara $^{1,}$, \\ Mahmoud Salah El-Tarabany ${ }^{3}$ \\ ${ }^{1}$ Biological Applications Department, Radioisotopes Applications Division, NRC, Atomic Energy Authority, Cairo, Egypt \\ ${ }^{2}$ Physiology Department, National Organization for Drug Control and Research (NODCAR), Cairo, Egypt \\ ${ }^{3}$ Department of Animal Wealth Development, Faculty of Veterinary Medicine, Zagazig University, Sharkia, Egypt
}

Email address:

eltarabanyakram@yahoo.com (A. A. S. El-Tarabany), ebntaimya@yahoo.com (O. A. H. Ahmed-Farid),

mahmoudtarabany2887@yahoo.com (M. S. El-Tarabany)

${ }^{*}$ Corresponding author

\section{To cite this article:}

Akram Abdel Sattar El-Tarabany, Omar Abdel Hamid Ahmed-Farid, Sana Sayed Emara, Mahmoud Salah El-Tarabany. Impact of Royal Jelly Supplement on Ewe's Milk Fat Content and Fatty Acid Profile During the Early Stage of Lactation. Advances in Applied Physiology.

Vol. 5, No. 2, 2020, pp. 37-41. doi: 10.11648/j.aap.20200502.15

Received: September 21, 2020; Accepted: October 12, 2020; Published: October 21, 2020

\begin{abstract}
The aim was to study the possible effects of royal jelly (RJ) supplementation on milk fat content and fatty acids (FA) profile of ewes during the early stage of lactation. Randomly, thirty-six Ossimi ewes were divided into two groups (18 animals each). The first group was offered the basal diet which was considered as a control group, whereas the second group was fed the basal diet, in addition to a supplement of a single bolus of RJ $(1000 \mathrm{mg} / \mathrm{head})$ every two days as a treated group. Regardless the effect of time, the RJ-supplemented group recorded a non-significant increase in daily milk yield (1.22 $\mathrm{kg}$ ) when compared with the control $(1.08 \mathrm{~kg})$ group $(\mathrm{P}<0.063)$. While, the RJ-supplemented ewes showed significantly increase in milk fat percentage $(\mathrm{P}<0.008)$ as compared to control group. Lactating ewes in the control group produced significantly higher contents of milk C14:0 ( $<<0.036)$ and $\mathrm{C} 18: 0(\mathrm{P}<0.027)$ saturated FA than that in the RJ group. However, the contents of milk C6:0 and $\mathrm{C} 17: 0$ in the RJ group were significantly greater than that estimated in the control ( $\mathrm{P}<0.050$ and 0.041 , respectively). Furthermore, Lactating ewes supplemented with RJ produced significantly higher contents of milk $\mathrm{C} 16: 1$ (P<0.001), C18:1 $(\mathrm{P}<0.001)$ and $\mathrm{C} 18: 2(\mathrm{P}<0.046)$ unsaturated FA than the control group. It can be concluded that supplementation of ewes during the early stage of lactation with RJ can improve the nutritive value of milk fat, and appears to be an opportunity to modify the concentrations of certain milk fatty acids.
\end{abstract}

Keywords: Royal Jelly, Lactating Ewes, Milk Yield, Fatty Acids

\section{Introduction}

In the few recent decades, natural additives have been extensively used in animal feeding due to their positive effects [1]. While, Beehive products are commonly used, as they contain some phenolic compounds which have several antimicrobial properties. To a certain degree, such compounds may modify the fermentation process in ruminants, based on their origin and supplementation level in the diets [2]. Accordingly, research has been practiced using beehive products; including royal jelly $(\mathrm{RJ})$, bee pollen and Propolis; for their biological functions and pharmaceutical benefits [3].

$\mathrm{RJ}$ is a secretion produced in the cephalic glands of nurse bees and serves as the most important part of honeybee larvae diet, while playing a major role in caste differentiation [4]. RJ is widely used in both folk and official medicine and is a controversial effectual and beneficial dietary supplement. It has a complex composition (water, proteins, lipids, carbohydrates, amino acids, mineral salts, vitamins, enzymes, hormones, oligo-elements and natural antibiotics) comprising $67 \%$ water, $12.5 \%$ crude protein (including small amounts of 
many different amino acids), $11 \%$ simple sugars (monosaccharides) and 5\% fatty acids. It also contains many trace minerals, some enzymes, antibacterial, antibiotic components and trace amounts of vitamin $\mathrm{C}[5,6]$. RJ has been associated with antioxidant, antibiotic, antiinflammatory, immunomodulatory, anti-allergic and general tonic pharmacological activities [7]. Meanwhile, information on the mechanism of action of chemical and bioactive compounds of RJ is not fully explored [8].

It has been known that milk fat contents and fatty acid (FA) profiles can be enhanced by make changes in composition of the diet for lactating animals, increasing the ability to respond to market preferences and human health requirements [9]. Additionally, flavonoids originating from beehive products have been found to alter the fermentation process in the rumen and simulate the ruminal digestion under laboratory conditions [10]. Therefore, the data about the effect of RJ on the milk fat contents and FA profile in lactating ewes are limited and controversial. Thus, the objective of the present study was to evaluate the possible effects of RJ supplements on milk fat contents and FA profiles in Ossimi ewes during the early stage of lactation.

\section{Materials and Methods}

This study was carried out at the experimental farms of the Nuclear Research Center, the Egyptian Atomic Energy Authority, which was conducted in the desert region of Inshas, Egypt.

\subsection{Animals, Experimental Design and Management}

Thirty-six multiparous ewes (Ossimi; $38 \pm 1.5 \mathrm{~kg}$ BW) were randomly selected. Phenotypically, all ewes are healthy and have symmetrical udders. After lambing, animals were monitored and accommodated to one of the experimental groups. At the 3rd day post-lambing, the selected ewes were assigned randomly into two equal groups (18 animals each). The first group was offered the basal diet which was considered as a control group, whereas the second group was fed the basal diet, in addition to a supplement of a single bolus of RJ (soft gelatin capsules; $1000 \mathrm{mg} / \mathrm{animal}$ ) every two days as a treated group. The current study continued for 4 weeks and completed under a temperate environmental conditions during the winter season $\left(23.2 \pm 1.2^{\circ} \mathrm{C}\right)$.
The crude RJ was collected and prepared by the Pharco Company (Royal Jelly 1000 mg, Pharco pharmaceuticals, Egypt). This commercial bolus form was prepared from a raw RJ that collected during the April month. At this time, the chemical composition of RJ is more stable and homogeneous. Using the gas chromatography-mass spectrometry (Shimadzu QP 2010 Plus, Japan), the chemical composition of RJ was calibrated according to [11]. The column of gas chromatography was a Zebron ${ }^{\mathrm{TM}}$ (ZB-1; ZB5MSplus Capillary GC) methyl poly siloxane $(30 \mathrm{~m} \times 0.25$ $\mathrm{mm}$ i.d. $\times 0.25 \mu \mathrm{m}$ film thickness). The chemical composition of RJ is described in Table 1. The main Flavonoids components are: Chrysin, Pinocembrin, Tectochrys in and Pinostrobinchalcone.

Table 1. The chemical composition (major flavonoids and fatty acids) of Royal Jelly.

\begin{tabular}{lll}
\hline Components & ${ }^{\mathbf{1}} \mathbf{T I C} \%$ & ${ }^{\mathbf{2}} \mathbf{R T}(\mathbf{m i n})$ \\
\hline 10-Hydroxydecanoic acid & 19.609 & 19.372 \\
Octanoic acid, 8-hydroxy & 3.138 & 14.791 \\
Pinocembrin & 1.844 & 33.72 \\
3-Hydroxydecanoic acid & 1.459 & 16.799 \\
Chrysin & 0.843 & 35.97 \\
Pinostrobinchalcone & 0.732 & 32.34 \\
Oleic acid amide & 0.679 & 32.407 \\
Furfuryl alcohol & 0.648 & 2.27 \\
Tectochrysin & 0.383 & 35.13 \\
\hline
\end{tabular}

${ }^{1} \mathrm{TIC} \%$ : The ion current generated depends on the characteristics of the compound concerned; ${ }^{2} \mathrm{RT}$ : Retention time.

Ewes were housed in a shaded free stall barn and the experimental groups were kept under the same environmental conditions. Feed allowances were offered once a day in the morning at10 a.m. individually, ewes fed the recommended diet with a subsequent measuring of daily feed intake for each animal. The basal diet was given in a form of wellformulated, mixed ration, before and after lambing. The concentrate mixture consisted of yellow corn, soybean, cottonseed cake, wheat bran, sugar beet bulb, and vitamin premix. On a dry matter basis, the analyses to explore the chemical composite of the diet were performed as described in Table 2 [12]. The alfalfa hay, straw, and concentrate were in a 35:20:45 ratios. The mixed ration was given in wellconstructed mangers (allowing feeder space $=0.40 \mathrm{~m}$ per animal). Fresh drinking water was available to all animals at all times in clean basins full of fresh water.

Table 2. Ingredients and chemical composition of the concentrate mixture during the experimental period.

\begin{tabular}{|c|c|c|c|c|c|c|c|}
\hline \multirow{2}{*}{ Item } & \multirow{2}{*}{${ }^{1} \mathbf{B D}$} & \multicolumn{6}{|c|}{ Ingredients } \\
\hline & & ${ }^{2} \mathrm{YC}$ & ${ }^{3} \mathrm{CSM}$ & ${ }^{4} \mathbf{W B}$ & ${ }^{5}$ SBB & ${ }^{6} \mathrm{AH}$ & ${ }^{7} \mathbf{S}$ \\
\hline \multicolumn{8}{|l|}{ Ingredients $(\%)$} \\
\hline Yellow corn & 25 & & & & & & \\
\hline Wheat bran & 20 & & & & & & \\
\hline Sugar beet bulb & 30.4 & & & & & & \\
\hline Soybean meal & 7 & & & & & & \\
\hline Undecorticated cotton seed meal & 15 & & & & & & \\
\hline Dicalcium phosphate & 1 & & & & & & \\
\hline Sodium chloride & 1 & & & & & & \\
\hline Mineral mixture* & 0.5 & & & & & & \\
\hline Vitamin mixture** & 0.1 & & & & & & \\
\hline Chemical composition (\%) & & & & & & & \\
\hline
\end{tabular}




\begin{tabular}{|c|c|c|c|c|c|c|c|}
\hline \multirow{2}{*}{ Item } & \multirow{2}{*}{${ }^{1} \mathbf{B D}$} & \multicolumn{6}{|c|}{ Ingredients } \\
\hline & & ${ }^{2} \mathrm{YC}$ & ${ }^{3} \mathrm{CSM}$ & ${ }^{4} \mathbf{W B}$ & ${ }^{5} \mathrm{SBB}$ & ${ }^{6} \mathrm{AH}$ & ${ }^{7} \mathbf{S}$ \\
\hline${ }^{8} \mathrm{CP}$ & 17.68 & 8.42 & 28.74 & 15.55 & 9.39 & 18.8 & 3.6 \\
\hline${ }^{9} \mathrm{CF}$ & 15.5 & 2.23 & 17.38 & 42.8 & 20.92 & 32.2 & 31.1 \\
\hline Fat (ether extraction) & 2.87 & 3.99 & 7.58 & 4.05 & 0.94 & 1.7 & 1.3 \\
\hline Nitrogen-free extract & 47.28 & 72.08 & 29.4 & 38.51 & 56.72 & 34.4 & 42.3 \\
\hline Ash & 6.01 & 1.29 & 5.15 & 4.96 & 11.63 & 7.7 & 16.4 \\
\hline Net energy $(\mathrm{MJ} / \mathrm{kg})$ & 6.32 & 14.17 & 7.94 & 9.04 & 3.42 & 6.8 & 4.1 \\
\hline
\end{tabular}

${ }^{1} \mathrm{BD}$ : basal diet (DM basis); ${ }^{2} \mathrm{YC}$ : yellow corn; ${ }^{3} \mathrm{CSM}$ : cotton seed meal; ${ }^{4} \mathrm{WB}$ : wheat bran; ${ }^{5} \mathrm{SBB}$ : Sugar beet bulb; ${ }^{6} \mathrm{AH}$ : alfalfa hay, ${ }^{7} \mathrm{~S}$ : straw; ${ }^{8} \mathrm{CP}$ : crude protein; ${ }^{9} \mathrm{CF}$ : crude fiber.

* mineral mixture contains: $5 \mathrm{~g} \mathrm{Cu}, 30 \mathrm{~g} \mathrm{Fe}, 40 \mathrm{~g} \mathrm{Mn}, 45 \mathrm{~g} \mathrm{Zn}, 0.3 \mathrm{~g} \mathrm{I}, 0.1 \mathrm{~g}$ Se and $881.6 \mathrm{~g} \mathrm{Caco3} / \mathrm{kg}$ mixture.

**vitamin mixture contains: 20 million (I.U) vit A, 2 million (I.U) vit D3 and $2 \mathrm{~g}$ vit $\mathrm{E} / \mathrm{kg}$ mixture.

\subsection{Milk Yield, Fat Content and Fatty Acids Profile}

Every day, all ewes tested for the presence of clinical signs of mastitis, such as high temperature, distressing response or glandular changes. In order to evaluate the daily milk yield, lambs were separated from their dams at 4 p.m, and being hand milked $(0800 \mathrm{~h})$ in the next morning [13]. Throughout the experiment (four consecutive weeks), this practice was done in each week. Hand milking had been practicing with two expert milkers have the same fitness. On a weekly basis and from each ewe, milk samples were collected $(100 \mathrm{ml}$ approximately). The samples of milk were kept save by the 2-bromo-2-nitropropane-1,3 diol product to detect the milk fat contents by a milk analyzer (MilkoScan 6000; Hillerød, Denmark).

On the 4th week of the experiment, one milk sample (100 $\mathrm{ml}$ approximately) was collected without the preservative from each animal and maintained frozen to determine milk FA composition. The concentrations of milk FA ( $\mathrm{g} / 100 \mathrm{~g}$ fat) were measured using the GC method [14]. The extraction of milk samples was prepared with Folch's solution, chloroform: methanol (2:1) then vortex for $2 \mathrm{~min}$ and centrifuged for 10 minutes at $4000 \mathrm{rpm}$. The trinonanoin was used as internal standard. The esterification procedure was completed by mix-up the supernatant with $2 \mathrm{ml}$ of a mix of (95: 5 methanol: sulphuric acid), at that point set it in an oven for $2 \mathrm{~h}$ (at 80 ${ }^{\circ} \mathrm{C}$ ), then extracted with $2 \mathrm{ml}$ hexane. Finally, samples were prepared for injection in the GC set loop.

SupelcoSP2330 columns $(30 \mathrm{~mm}$ X $0.32 \mathrm{~mm}$ X $0.2 \mu \mathrm{m}$ film thickness) were standardized and used as described by the standard protocols (Cat. No. 24073, Sigma-Aldrich, St. Louis, MO, USA). The standardized Gas chromatography was performed with an Agilent Technologies (7890A GC, Agilent Technologies, Inc, USA). The flow rates at the split vent and through the column were 50 and $2.5 \mathrm{ml} / \mathrm{min}$, respectively. Initially, the gradient temperature started with $70^{\circ} \mathrm{C}$ and linearly increased to $170^{\circ} \mathrm{C}\left(20^{\circ} \mathrm{C} / \mathrm{min}\right)$. Further, a delayed linear increase to $170^{\circ} \mathrm{C}\left(0.8^{\circ} \mathrm{C} / \mathrm{min}\right)$ was practiced to separate the closely-eluting fatty acids, followed by an increase to reach $220^{\circ} \mathrm{C}\left(20^{\circ} \mathrm{C} / \mathrm{min}\right)$, and a final $2.5 \mathrm{~min}$ hold. Considering the flame ionization detector (FID), the whole run time was 20.1 minutes. The major milk saturated and unsaturated fatty acids were considered in this study.

\subsection{Statistical Analysis}

The normality of the available data was confirmed by
Kolmogorov-Smirnov test $(\mathrm{P}>0.05)$. The repeated measure data (daily milk yield and milk fat contents) were interpreted using the repeated measures analysis of variance as a MIXED procedure of SAS statistical system Package (SAS Institute, Cary, NC, USA). The model for repeated measures was defined as: $y i j k=\mu+\mathrm{Ti}+$ Ewe $(\mathrm{Ti}) \mathrm{j}+$ Timek $+($ Time $\times \mathrm{T})$ $\mathrm{ki}+$ eijk, where, yijk=daily milk yield and milk fat contents, $\mathrm{Ti}=$ fixed effect of treatment, Ewe (Ti) $\mathrm{j}=$ random effect of ewe nested in treatment, Timek=fixed effect of time, (Time $\times$ T) $i k=$ interaction of time and treatment, and eijk=random error term.

Regarding the milk FA profile, the model was fitted to include the fixed effects of treatment (two levels: CON and RJ, parity (two levels: primiparous and multiparous) and the random effects of the dairy animal nested within parity. The differences between the means of the control and treated group were determined by a Student's t-test adjusted with a Tukey correction.

\section{Results}

Regardless the effect of time, the RJ-supplemented group recorded a non-significant increase in daily milk yield (1.22 $\mathrm{kg})$ when compared with the control $(1.08 \mathrm{~kg})$ group $(\mathrm{P}<0.063)$. The influence of the RJ on milk fat contents is illustrated in Figure 1. Regardless the effect of time, the RJsupplemented ewes produced significantly higher milk fat percentage than the control group $(\mathrm{P}<0.008)$. However, the effect of time on the milk fat percentage was non nonsignificant $(\mathrm{P}<0.068$, as a repeated measure value).

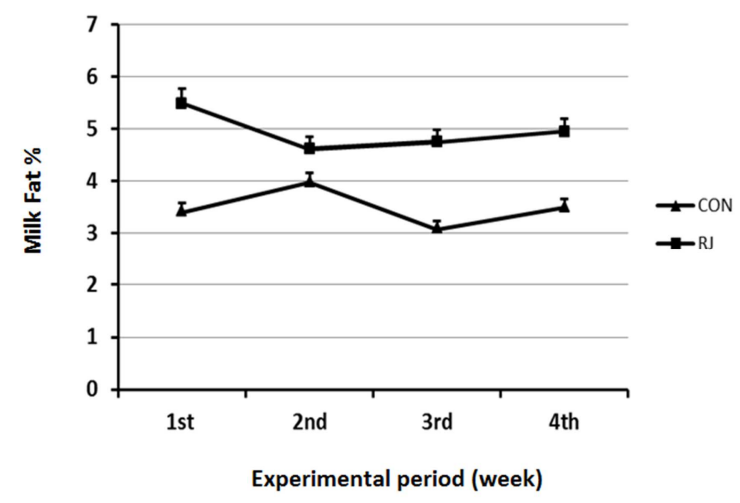

Figure 1. Effect of royal jelly $(R J)$ supplement on the percentage of milk fat in lactating ewes $(P<0.008)$. The effect of time on the milk fat percentage was non non-significant $(P<0.068$, as a repeated measure value)). 
Table 3. Milk Fatty acid profile ( $g / 100 \mathrm{~g}$ of total lipids) of lactating ewes supplemented with Royal Jelly.

\begin{tabular}{|c|c|c|c|c|}
\hline \multirow{2}{*}{ Fatty acids } & \multicolumn{2}{|c|}{ Experimental groups } & \multirow{2}{*}{ SEM $^{3}$} & \multirow{2}{*}{$\begin{array}{l}\text { P- } \\
\text { values }\end{array}$} \\
\hline & $\mathrm{CON}^{1}$ & $\mathbf{R J}^{2}$ & & \\
\hline $\mathrm{C} 4: 0$ & 3.41 & 4.39 & 0.21 & 0.163 \\
\hline C6:0 & 3.96 & 4.67 & 0.24 & 0.050 \\
\hline C8:0 & 2.57 & 3.64 & 0.09 & 0.098 \\
\hline C10:0 & 6.68 & 9.02 & 0.29 & 0.103 \\
\hline $\mathrm{C} 12: 0$ & 3.68 & 5.08 & 0.28 & 0.083 \\
\hline C14:0 & 10.94 & 6.87 & 0.69 & 0.036 \\
\hline C15:0 & 1.70 & 1.71 & 0.10 & 0.603 \\
\hline C16:0 & 25.61 & 25.24 & 0.71 & 0.320 \\
\hline $\mathrm{C} 17: 0$ & 2.34 & 3.09 & 0.16 & 0.041 \\
\hline C18:0 & 12.48 & 7.43 & 0.56 & 0.027 \\
\hline C14:1 & 0.113 & 0.144 & 0.02 & 0.383 \\
\hline C16:1 & 0.647 & 0.907 & 0.03 & 0.001 \\
\hline C18:1 & 0.506 & 0.692 & 0.05 & 0.001 \\
\hline C18:2 & 2.01 & 2.49 & 0.08 & 0.046 \\
\hline $\mathrm{C} 20: 1$ & 0.111 & 0.146 & 0.004 & 0.356 \\
\hline $\mathrm{C} 20: 4$ & 0.167 & 0.211 & 0.005 & 0.085 \\
\hline $\mathrm{C} 20: 5$ & 0.018 & 0.023 & 0.001 & 0.436 \\
\hline
\end{tabular}

${ }^{1} \mathrm{CON}$ : control group; ${ }^{2} \mathrm{RJ}$ : Royal jelly-supplemented group; ${ }^{3} \mathrm{SEM}$ : standard error mean

The effects of RJ on the contents of milk FAs (g/100g fat) in dairy ewes are described in Table 3. Lactating ewes in the control group produced significantly higher contents of milk C14:0 $(\mathrm{P}<0.036)$ and $\mathrm{C} 18: 0(\mathrm{P}<0.027)$ saturated FAs than that in the RJ group. However, the contents of milk C6:0 and $\mathrm{C} 17: 0$ in the RJ group were significantly greater than that recorded in the control group $(\mathrm{P}<0.050$ and 0.041, respectively).

Additionally, no significant variations were recorded in the contents of milk FAs, C4:0, C8:0, C10:0, C12:0, C15.0 and $\mathrm{C} 16: 0$ in both of RJ-supplemented and control groups. Lactating ewes supplemented with $\mathrm{RJ}$ produced significantly higher contents of milk C16:1 $(\mathrm{P}<0.001), \mathrm{C} 18: 1 \quad(\mathrm{P}<0.001)$ and $\mathrm{C} 18: 2(\mathrm{P}<0.046)$ unsaturated FAs than the control group. Contrarily, no considerable differences were reported in the contents of milk FAs, C14:1, C20:1, C20:4 and C20:5.

\section{Discussion}

Commercially, the dietary supplements of RJ were ready for use in a form of soft gelatin cap containing $1000 \mathrm{mg}$ of natural product. Although the current study reported nonsignificant increases in milk yield in the RJ group, the percentage of milk fat was significantly improved. Similarly, the propolis increased milk yield and fat content $(\mathrm{P}<0.05)$ of the supplemented ewes compared with control [15]. Furthermore, both experimental groups in the present trial be given identical energy density in the $\operatorname{diet}(6.36 \mathrm{MJ} / \mathrm{kg})$, with a possible mechanism that stabilize the energy metabolism in lactating RJ-supplemented animals.

Keeping in mind, that milk fat contents are synthesized in the epithelial tissue of the udder alveoli, the positive effect of RJ may attribute to its chemical component and especially to its major proteins, which play an essential role in the cell membrane benignity [16]. The rate of lipid peroxidation was elevated when the level of milk polyunsaturated FAs is increased [17]. Hence, the preferable milk fat constituent in the RJ group support the viable protective mechanism of phenolic compounds of RJ on plasma lipids, maybe by catch the free radicals or binding with metal ions [18]. On contrast, the propolis supplement did not affect the milk fat contents in dairy cows [1].

The changes in milk FAs contents can be attributed to the altered fermentation process in the rumen, and consequently, to the lipid metabolism. However, common biological benefits of RJ are due to a natural mixture of its components (flavonoids and organic compounds). Regarding the fatty acid profile, Milk from RJ-supplemented ewes had significantly lower contents of saturated Tetradecanoic (C:14) and Octadecanoic (C:18) FAs. The variability of saturated FAs contents in the control and RJ-supplemented ewes suggest that de novo fatty acid synthesis was influenced by supplementation of RJ.

Further, other feed additives as flaxseed oil caused reduction in milk saturated FA contents [19]. What's more, lactating ewes supplemented with RJ produce significantly higher contents of milk Palmitoleic (C16:1), Oleic (C18:1) and Linoleic (C18:2) unsaturated FAs than that noticed in the control group. The increase in the components of milk Oleic and Linoleic unsaturated FAs in the RJ-supplemented ewes may be due to the inhibitory action on the initial step of the ruminal biohydrogenation process. The propolis supplement suppress the growth of some species of rumen bacteria, such as Butyrivibrio fibrisolvens and Ruminococcus albus [20].

The phenolic compounds from the beehive products may be acting on these bacterial species in the biohydrogenation process, thus altering the components of the Linoleic isomers in milk fat. It is believed that unsaturated FAs are unsteady and easily affected by a loss of electrons and further oxidative processes [19]. Taking into consideration, the physiological functions of RJ and its remarkable antioxidant effects, this may elucidate its beneficial and protective effects on milk unsaturated FAs contents.

\section{Conclusion}

The RJ supplement improved the nutritional merits of milk fat in lactating Ossimi ewes by increasing the contents of milk Palmitoleic (C16:1), Oleic (C18:1) and Linoleic (C18:2) unsaturated FAs, and the contents of milk Hexanoic (C6:0) and Heptadecanoic (C17:0) saturated FAs. In a recommendation to use $\mathrm{RJ}$ in the diets of the animals producing milk to increase the nutritional value of milk and its quality for consumer. In Taking into consideration that the present study is a preparatory trial, the action of RJ in lactating animals still need to extra investigation to determine the effective treatment full length, perfect dose, and mode of action.

\section{Ethical Standards}

The experimental procedures of the present research were 
approved by the Nuclear Research Center, Atomic Energy Authority, Egypt.

\section{Conflict of interest}

The authors declare that they have no competing interests.

\section{References}

[1] Aguiar, S. A., et al., Effect of feeding phenolic compounds from propolis extracts to dairy cows on milk production, milk fatty acid composition, and the antioxidant capacity of milk. Animal Feed Science and Technology, 2014. 193: p. 148-154.

[2] Narvaez, N., et al., Effects of California chaparral plants on in vitro ruminal fermentation of forage and concentrate diet. Journal of the Science of Food and Agriculture, 2013. 93 (3): p. $550-559$.

[3] Seven, İ., et al., The effects of propolis and vitamin C supplemented feed on performance, nutrient utilization and carcass characteristics in broilers exposed to lead. Livestock Science, 2012. 148 (1): p. 10-15.

[4] El-Hanoun, A. M., et al., Impact of royal jelly to improve reproductive performance of male rabbits under hot summer conditions. J World Rabbit Science, 2014. 22 (3): p. 241-248.

[5] Graham, J. M., The hive and the honey bee. 1992, Revised edition. Dadant and Sons, Hamilton, Illinois, USA.

[6] Seven, I., et al., The effects of royal jelly on performance and fatty acid profiles of different tissues in quail (Coturnix coturnix japonica) reared under high stocking density. Turkish Journal of Veterinary and Animal Sciences 2014. 38 (3): p. 271-277.

[7] Mărghitaş, L., Produsele apicole şi principalele lor însuşiri terapeutice. J Albinele şi produsele lo, 2008: p. 280-378.

[8] Pavel, C. I., et al., Biological activities of royal jelly-review. J Scientific Papers Animal Science, 2011. 44 (2): p. 108-118.
[9] Lock, A. L. and K. Shingfield, Optimising milk composition. J BSAP Occasional Publication, 2004. 29: p. 107-188.

[10] ÖZTURK, H., et al., Effects of propolis on in vitro rumen microbial fermentation. Ankara Üniv. Vet. Fak. Derg., 2010. 57: p. 217-221.

[11] Cardenia, V., et al., Analysis of cholesterol oxidation products by fast gas chromatography/mass spectrometry. Journal of separation science, 2012. 35 (3): p. 424-430.

[12] AOAC, Official Methods of Analysis. Association of Official Analytical Chemists. 1990, 15th ed. AOAC, Arlington, Virginia, USA.

[13] Linda de Bie, Y. and D. Thomas, The effect of three times a day milking at the beginning of lactation on the milk production of East Friesian crossbred ewes. 2001. 39.

[14] Ren, J., et al., Total serum fatty acid analysis by GC-MS: assay validation and serum sample stability. J Current pharmaceutical analysis, 2013.9 (4): p. 331-339.

[15] Morsy, A. S., et al., Impact of Brazilian red propolis extract on blood metabolites, milk production, and lamb performance of Santa Inês ewes. Tropical Animal Health and Production, 2016. 48 (5): p. 1043-1050.

[16] Tamura, S., et al., Estimation and characterisation of major royal jelly proteins obtained from the honeybee Apis merifera. J Food Chemistry, 2009. 114 (4): p. 1491-1497.

[17] Zhao, X. a., et al., Effects of different fat mixtures on milk fatty acid composition and oxidative stability of milk fat. Animal Feed Science and Technology, 2013. 185 (1): p. 35-42.

[18] Lindmark-Månsson, H. and B. Åkesson, Antioxidative factors in milk. British Journal of Nutrition, 2000. 84 (S1): p. 103-110.

[19] Santos, N.,;, et al., Antioxidant effects of a propolis extract and vitamin $\mathrm{E}$ in blood and milk of dairy cows fed diet containing flaxseed oil. Livestock Science, 2016. 191: p. 132138.

[20] Aguiar, S., et al., Antimicrobial activity of Brazilian propolis extracts against rumen bacteria in vitro. World Journal of Microbiology and Biotechnology, 2013. 29 (10): p. 1951-1959. 